\title{
How the tobacco industry built its relationship with Hollywood
}

\section{Mekemson, S A Glantz}

Tobacco Control 2002;11(Suppl I):i81-i91

See end of article for authors' affiliations

\section{................. \\ Correspondence to:} Stanton A Glantz, PhD,

Division of Cardiology, Box 0130, University of California, San Francisco San Francisco, CA 94143, USA;

glantz@medicine.ucsf.edu entertainment industry.

Methods: Review of previously secret tobacco industry documents available on the internet.

Results: Both the entertainment and tobacco industries recognised the high value of promotion of tobacco through entertainment media. The 1980s saw undertakings by four tobacco companies, Philip Morris, RJ Reynolds (RJR), American Tobacco Company, and Brown and Williamson to place their products in movies. RJR and Philip Morris also worked to place products on television at the beginning of the decade. Each company hired aggressive product placement firms to represent its interests in Hollywood. These firms placed products and tobacco signage in positive situations that would encourage viewers to use tobacco and kept brands from being used in negative situations. At least one of the companies, RJR, undertook an extensive campaign to hook Hollywood on tobacco by providing free cigarettes to actors on a monthly basis. Efforts were also made to place favourable articles relating to product use by actors in national print media and to encourage professional photographers to take pictures of actors smoking specific brands. The cigar industry started developing connections with the entertainment industry beginning in the 1980s and paid product placements were made in both movies and on television. This effort did not always require money payments from the tobacco industry to the entertainment industry, suggesting that simply looking for cash payoffs may miss other important ties between the tobacco and entertainment industries.

Conclusions: The tobacco industry understood the value of placing and encouraging tobacco use in films, and how to do it. While the industry claims to have ended this practice, smoking in motion pictures increased throughout the 1990s and remains a public health problem.
$\mathrm{T}$ he tobacco industry recruits new smokers by associating its products with fun, excitement, sex, wealth, and power and as a means of expressing rebellion and independence. One of the ways it has found to promote these associations has been to encourage smoking in entertainment productions. ${ }^{1}$ Exposure to smoking in entertainment media is associated with increased smoking and favourable attitudes towards tobacco use among adolescents. ${ }^{2-8}$

Product and brand exposure in films is the result of paid product placement, the provision of free products as props, or personal use by actors. Product placement implies a mutually beneficial relationship between the filmmaker and the manufacturer of the product. Initial contact may be made by the filmmaker seeking to reduce costs, increase income, and provide realism or it may be made by product placement firms seeking product exposure for companies they represent. Product placement firms have evolved over the last two decades to broker relationships between filmmakers and corporations. The usual procedure is for the product placement firm to receive scripts in advance of production from filmmakers and review the scripts for the possible use of products they represent. Normally this involves substituting a specific brand for a generic brand-that is, instead of "John meets Mary at a coffeehouse", John might meet Mary at Curt's Coffee. The integrity of the script is maintained, a touch of realism is provided, the filmmaker has an existing location for filming, and Curt's Coffee receives extensive free exposure. The film cast and crew may also receive free lattes and muffins and possibly Curt's Coffee mugs. The product placement firm receives its fee for making the placement, and everyone connected with making the film wins.

While the tobacco industry has routinely denied active involvement in entertainment programming, previously secret tobacco industry documents made available in the USA show that the industry has had a long and deep relationship with Hollywood. Placing tobacco products in movies and on televi- sion (fig 1), encouraging celebrity use and endorsement, advertising in entertainment oriented magazines, designing advertising campaigns to reflect Hollywood's glamour, and sponsoring entertainment oriented events have all been part of the industry's relationship with the entertainment industry.

\section{METHODS}

Over 1500 documents on tobacco industry relations with the entertainment industry were reviewed on the websites of Philip Morris, RJ Reynolds (RJR), Brown and Williamson/ American Tobacco, the Lorillard Company, and the Tobacco Institute, and the University of California digital collection of tobacco industry documents. Initial search parameters included a listing of major studios, selected actors who are known to commonly use tobacco in movies, and key words such as product placement, movies, and cinema advertising. All leads were then followed up using names of individuals and organisations identified in the first pass.

Because the documents resulted from litigation against the tobacco industry which occurred in the mid-1990s, most available documents end at about that time.

\section{RESULTS}

The value of entertainment media to promote tobacco Tobacco use in movies and television is a subtle and powerful form of promotion. The value of this form of advertising is

Abbreviations: AFP, Associated Film Promotions; AMA, American Medical Association; ATC, American Tobacco Company; B\&W, Brown and Williamson; FTC, Federal Trade Commission; GASP, Massachusetts Group Against Smoke Pollution; RJR, RJ Reynolds; STAT, Stop Teenage Addiction to Tobacco; TUTD, Thumbs Up! Thumbs Down! Project; UPP, Unique Product Placements 

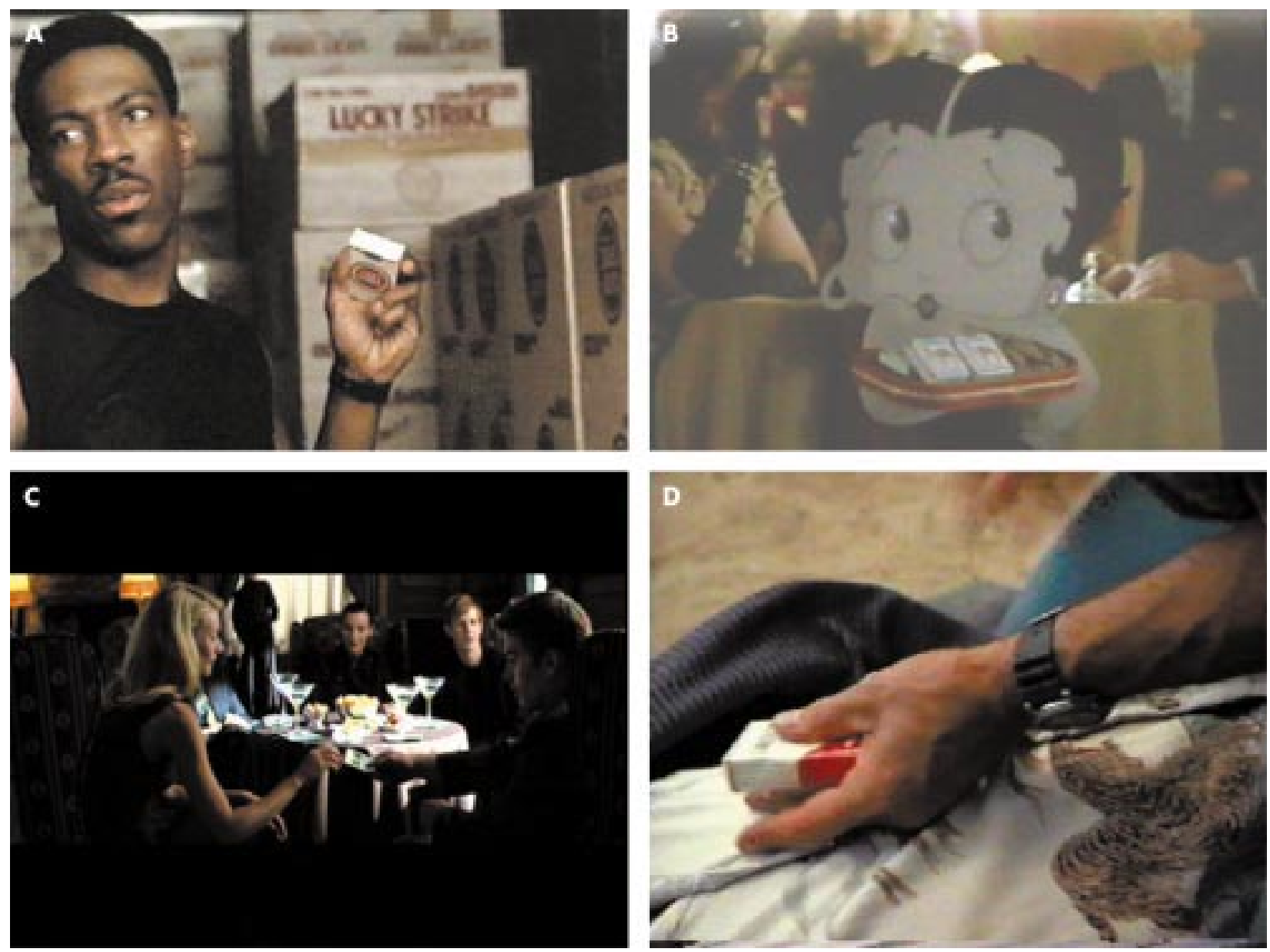

Figure 1 Some examples of brand placement and depiction in movies. (A) Eddie Murphy featuring Luck Strike in Beverly Hills Cop (1984), (B) Betty Boop featuring Camels in Who Framed Roger Rabbit? (1988), (C) Gwyenth Paltrow and Ethan Hawke featuring Kools in Great Expectations (1998), (D) Jim Carrey featuring Marlboros in Me, Myself, and Irene (2000). The tobacco industry voluntary code purports to end product placement in films after 1990.

emphasised frequently in tobacco industry documents relating to product placement. In a letter dated 25 August 1972, Robert Richards, president of Productions Inc, a movie and television production company, points out to William Smith, president of RJR, that all of the major characters and supporting people smoke in a suspense thriller that Productions Inc was creating. He then adds: "film is better than any commercial that has been run on television or any magazine, because the audience is totally unaware of any sponsor involvement . . ."' [emphasis added].

A sales pitch in 1987 by the product placement firm of Baldwin, Varela and Company promoting the movie Eight Men Out to Ligget \& Meyers emphasises a similar message: "based on its story, cast and subject matter, this film will appeal to young audiences attending to see their favorite leading actors . . . Billboard sponsorship provides an opportunity to deliver subtle but powerful institutional and product messages to a young group, still in the stages of forming purchasing habits." ${ }^{10}$ Ligget declined on the basis that company policy was not to have its products featured in films aimed at young

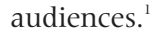

One of the most powerful arguments for exploiting entertainment productions was included in a 1989 Philip Morris marketing plan:

"We believe that most of the strong, positive images for cigarettes and smoking are created by cinema and television. We have seen the heroes smoking in "Wall
Street", "Crocodile Dundee", and "Roger Rabbit". Mickey Rourke, Mel Gibson and Goldie Hawn are forever seen, both on and off the screen, with a lighted cigarette. It is reasonable to assume that films and personalities have more influence on consumers than a static poster of the letters from a B\&H pack hung on a washing line under a dark and stormy sky. If branded cigarette advertising is to take full advantage of these images, it has to do more than simply achieve package recognition-it has to feed off and exploit the image source."

A correlation between product exposure in movies and the ability of young people to recall and recognise products featured was made in a report by Associated Film Promotions (AFP) to Brown and Williamson in September of $1981 .{ }^{13}$ In an effort to quantify recall ability, AFP carried out an extensive exit survey of patrons attending the movie "Cannonball Run", which showed people using Camels, Winstons, and Redman tobacco. While recall ability varied based on products, respondents under 18 had the best overall recall rates and the highest recall for tobacco products. Camel cigarettes had a $100 \%$ recall rate for those under 18 years old, $73 \%$ for the $18-35$ age bracket, and $69 \%$ of those 36 and over. Winston was recalled by $58 \%$ of those under $18,47 \%$ of those between $18-35$, and $38 \%$ of those 36 and over. The recall rate on Redman tobacco was $25 \%$ by those under 18 , and $0 \%$ by the other two age categories. 
The impact of this advertising, the advantage of associating products with leading actors, and the potential of appealing to younger audiences provided strong incentives for the tobacco industry to become involved with the entertainment industry in using movies to promote tobacco.

In addition to its value as advertising to recruit and retain smokers, the tobacco industry recognised, at the highest levels, the value of smoking in the movies as a way to maintain its social acceptability and shore up the industry's political position. A 1983 draft speech prepared for Hamish Maxwell, president of Phillip Morris' International and soon to be chairman of the board of Phillip Morris, to be delivered at a Phillip Morris' international marketing meeting, outlined the political difficulties that the industry was experiencing worldwide as countries were increasing taxes on cigarettes and restricting advertising. He saw smoking in the movies as one way that the industry could counter these trends:

"Recently, anti-smoking groups have also had some early successes at eroding the social acceptability of smoking. Smoking is being positioned as an unfashionable, as well as unhealthy, custom. We must use every creative means at our disposal to reverse this destructive trend. I do feel heartened at the increasing number of occasions when I go to a movie and see a pack of cigarette in the hands of the leading lady. This is in sharp contrast to the state of affairs just a few years ago when cigarettes rarely showed up in cinema. We must continue to exploit new opportunities to get cigarettes on screen and into the hands of smokers. The PMI Corporate Affairs Department is helping. The Department is working with Dr Sgerwin Feinhandler from Harvard University and Michael Dowling of Ogilvy and Mather to develop and international approach to this problem. ${ }^{\prime 14}$

Phillip Morris was approaching the problem of promoting smoking in the movies systematically and at the highest levels.

\section{Tobacco product placement initiated by the tobacco industry}

RJ R, Philip Morris, American Tobacco, and Brown \& Williamson actively sought relationships with Hollywood by contracting with various product placement firms based in Los Angeles. We describe each company's activities below. Table 1 shows a time line which relates the different companies' actions.

RJ Reynolds

RJ Reynolds (RJR) hired the Los Angeles based public relations firm, Rogers and Cowan*: "Beginning in 1980, ... to develop a strong relationship with the television and motion picture industry, and keep the presence of smoking and the

Table 1 Chronology of tobacco industry activities regarding smoking in motion pictures since 1970

1972 Productions Inc, a movie and television company, points out to RJ Reynolds that product placement in movies is "better than any commercial that has been run on television or any magazine, because the audience is totally unaware of any sponsor involvement"

1978 Phillip Morris begins working with Charles Pomerance to place tobacco products in movies

1979 Brown and Williamson (B\&W) contracts with the product placement firm of Associated Film Promotions for placing B\&W products in movies

1979 Phillip Morris pays to have Marlboros featured in the movie Superman II

1980 RJ Reynolds (RJR) contracts with Rogers and Cowan to develop a relationship with the television and movie industry which includes product placement, providing free product to key entertainment industry workers and promoting star use of RJR products through national media

1982 American Tobacco contracts with Unique Product Placement to place American Tobacco Products in films.

1982 Rogers and Cowan reports to RJR that they have arranged to have Sean Connery and others smoke Winston and Camel cigarettes in Never say Never Again for $\$ 10000$

1983 In spring, B\&W launches a campaign placing cigarette ads in 3000 movie theatres. During July, a Kool ad is run during the " $G$ " rated Disney film Snow White in Boston; anti-smoking activists create extensive controversy

1983 In fall, B\&W implements a critical audit of relationship with Associated Film Promotions questioning effectiveness and control of product placement programme

1984 B\&W cancels product placement and in-theatre ad programmes

1984 Twentieth Century Fox Licensing and Merchandising Corporation seeks tobacco company product placement agreements which would feature products and guarantee exclusivity in films for $\$ 20000$ to $\$ 25000$ per film

1988 Phillip Morris pays $\$ 350000$ for use of Larks in James Bond movie License to Kill and for rights to run a media promotion effort to coincide with the movie's opening in Japan

1989 Phillip Morris marketing study notes most "strong, positive images for cigarettes and smoking are created and perpetuated by cinema and television"

1989-90 Public hearings on product placement by Congressman Thomas Luken's Subcommittee on Transportation, Tourism and Hazardous Materials

1990 US Federal Trade Commission (FTC) inquiry into product placement activities of various tobacco firms

1990 RJR International contracts with Rogers and Cowan International for the placement of RJR products in films produced outside of the USA

1990 Cigarette companies modify voluntary Cigarette Advertising and Promotion Code to prohibit paid product placement

1991 After falling through the 1960s, 1970s, and 1980s, the frequency of smoking in the movies begins a rapid increase

1992 UPP contract with American Tobacco is modified to limit UPP's efforts with filmmakers to being reactive rather than proactive

1996/97 FTC notes that expenditures by the cigar industry for "celebrity endorsements, and appearances, and payment for product placement in movies and television more than doubled between 1996 and 1997"

1998 The Cigar Manufacturers' Association adopts a voluntary policy discouraging (but not outlawing) paid and donated cigar placements in movies and on television

1998 The Master Settlement Agreement prohibits participating cigarette manufacturers from product placement activities

2000 Average amount of smoking in movies exceeds levels observed in the 1960s

2001 Studies of films during the 1990s find continuing brand use depiction in movies with about $80 \%$ of the exposures being Philip Morris products, primarily Marlboro. Identifiable brand use by high profile stars is higher than before the tobacco industry's voluntary restrictions on product placement in movies 
RJR brands as an integral part of the industry." ${ }^{15}$ A letter dated 4 May 1981 from Warren Cowan, president of the firm, to Gerald Long, executive vice president of RJR, outlines the breadth of his activities on behalf of RJR. ${ }^{16}$ He notes: "Our primary objective will remain the same, to have smoking featured in a prominent way, especially when it is tied favorably with celebrities" [emphasis added]. Criteria for placement in a film include: (1) "positive exposure", (2) that the stars are people "with whom we would want the product associated", and (3) if "we could work the product into the script" ${ }^{16}$ Movies in which Rogers and Cowan claimed they successfully placed RJR products included The Jazz Singer with Neil Diamond, Backroads with Sally Field, Cannonball Run with Burt Reynolds, Pennies from Heaven with Steve Martin, Blowout with John Travolta, and "many, many others".

Cowan also targeted television. He wrote: "Encouraging smoking on television is another area and our work in this area ranges from our personal contacts with celebrities encouraging them to smoke on the air to supplying green rooms of the major TV talk shows, the Tonight Show, Merv Griffin, Mike Douglas, etc, with quantities of products for their guests ... During the last few days we have been able to get Zsa Zsa Gabor and Harold Robbins to smoke during the taping of the Merv Griffin Show ..."'16

Another activity to "keep the presence of smoking and the RJR brands as an integral part of the industry" was "writing and placing favorable stories" in the print media. ${ }^{16}$ Examples included a story about "Paul Newman practicing lighting two cigarettes for a remake of the New Voyager" and another about "Mikhail Baryshnikov smoking four packs of cigarettes a day as part of his routine". They also arranged "for celebrities to be photographed with the products" by working with fashion photographers to "have stars and models pose with cigarettes". ${ }^{16}$

A way to assure continuing tobacco use in entertainment productions was to encourage personal use by key industry leaders. Cowan reported that they were "adding to our list of celebrities and entertainment industry executives who smoke and sending them the product on a regular basis". ${ }^{16}$ In an earlier report to RJR dated 21 October 1980, he gives an excellent example of the potential results for this type of effort. After supplying a long list of celebrities the company was providing with free product, including Maureen O'Sullivan, Rex Reed, Liv Ullman, Shelley Winters, and Jerry Lewis, Cowan notes: "We also received additional thank you calls for the product. One from John Cassavettes (and wife Gena Rowlands), came with the assurance that he will use our product in his next film-and to tell us that, because of the samples we provided, he switched from Marlboro to Winstons." ${ }^{17}$ Later, in 1982, they reported that the stars of Lorimar TV Productions' Falcon's Crest, Dallas, and Knot's Landing were to receive monthly mailings of their favourite RJR brand. "In addition to having these stars smoke our brands in their personal appearances and private lives, we are seeking additional on-camera smoking scenes in their series." ${ }^{18}$

Rogers and Cowan provided RJR with regular reports of its successful placement efforts. Excerpts from early reports provide further insight into Rogers and Cowan's activities. A report dated 26 August 1981 from Cowan to RJR mentions

${ }^{*}$ In its present day website (rogersandcowan.com), the company emphasises that "extensive entertainment contacts and resources help us create an interest and 'buzz' around products that goes beyond traditional publicity effort". Regarding product placements, Rogers and Cowan notes that it "presents clients' products to producers, property masters, set decorators and costumers for inclusion in films and television". The company first contracted with RJR in 1980 to make use of its entertainment industry expertise, but gradually expanded its efforts to a number of other public relations activities. that the goal is to place products in movies with "pleasant situations" and goes on to stress that there "are films we have approached which we believe could be very beneficial to our 'subliminal' product campaign". ${ }^{19}$ Extensive contacts within the industry are a critical element in successful product placement. Cowan notes that "through our contacts with awardwinning director Samuel Fuller, we arranged for Paul Winfield to enjoy one of our products in the film White Dog". ${ }^{19}$ In the movie Second Thoughts, arrangements are made through "producer Dave Foster to have our products used and displayed in the film". ${ }^{19}$

Media opportunities beyond product placement are not overlooked. Taking advantage of the movie Blow Out, starring John Travolta and Nancy Allen in 1981, Cowan reports: "scenes of Travolta using our product appeared in many publications across the nation including US Magazine." ${ }^{19}$ Cowan also reported on other print media efforts to "plant items and photos in relation to our product".

This report also outlines other efforts to keep Hollywood celebrities personally using tobacco. Cowan states: "We recently completed a special mailing to female celebrities inviting them to try the new More Light 100s." ${ }^{19}$ Some actresses had responded that they "enjoyed the product and look forward to receiving More Lights on a regular basis" ${ }^{\prime 19}$ [emphasis added].

Although direct money payments for product placement are rarely mentioned in the industry documents, the James Bond movie Never Say Never Again was a notable exception. In a report dated 3 September 1982 to RJR, Frank Devaney, who would become Rogers and Cowan's contact with RJR, reports that for "a financial consideration of [US] $\$ 10,000$, the producers have agreed that Sean Connery, and other principal players, will smoke Winston and Camel cigarettes. A Salem spirit billboard [the Salem advertising campaign at the time] will be used in an action scene. No other cigarette company will be represented." ${ }^{20}$

Another important role played by the product placement specialists was to protect their brands from any negative exposure. Superman III actually lost RJR financial support. The youth oriented Superman II had received money from Philip Morris for Marlboro exposure and Rogers and Cowan was eager to replace the competition. Unfortunately, from Rogers and Cowan's perspective, the director was not cooperating. All "negotiations and agreements to pay for any exposure in [Superman III] were terminated" when "it was decided by the producer and director that they could not change a key scene" which showed cigarettes in an unsuitable light. ${ }^{20}$

\section{Philip Morris}

Philip Morris began its modern product placement efforts as early as 1978. Working initially through Charles Pomerance and later through Andrew Varela, Philip Morris reported placing its products in over 191 movies between 1978 and 1988. Forty eight of these movies had a "PG" (parental guidance) rating, 10 had a "PG-13" rating and 9l an "R" (restricted viewing) rating. There was even one " $G$ " (general) rated film, The Muppet Movie. Twenty nine movies were not rated and seven movies were made for TV including HBO (Home Box Office) and PBS (Public Broadcast Service). Product placement on PBS included a special, Maricela, which was awarded the Best Children's Script by the Writer's Guild. Philip Morris also reported supplying product to five MTV music videos during the time period. Among the notable movies listed as featuring Philip Morris cigarettes over the 10 years were Grease, Rocky II, Airplane, Little Shop of Horrors, Crocodile Dundee, Die Hard, Who Framed Roger Rabbit, and Field of Dreams. ${ }^{21}$

There were two highly publicised incidents of Philip Morris paying for product placements during this period, both of which would receive substantial attention during the late 1989 Congressional Hearings on product placement. The first 
was in the movie Superman II, which involved a detailed contract dated 18 October 1979 between Dovemead Ltd, the producers of the movie, and Philip Morris, Europe. ${ }^{22}$ Marlboro was to be featured in the movie and, in return, Philip Morris was to pay Dovemead UK£20 000. If there was any reference in the edited footage that might "reasonably be construed as detrimental to the Marlboro brand name", Dovemead agreed to remove all "exposure of the material from the release print of the film".22

The second movie was a James Bond feature, License to Kill, originally titled License Revoked. The arrangements for this film are included in a memo from Leo Burnett's Japanese division to Danjaq SA in Lausanne, Switzerland on 14 September $1988 .^{23}$ (Leo Burnett, Philip Morris's advertising agency, developed the Marlboro Man.) The terms of the agreement included the use of a Lark cigarette pack as a bomb detonator by Bond. It also gave Leo Burnett the rights to run a Lark media promotion in Japan to coincide with the opening of the movie. Danjaq also agreed, "that with the exception of cigar products, the film will contain no other visual or oral reference to any brand of tobacco products other than Lark . ..". ${ }^{23}$ In return for these considerations, Leo Burnett agreed to pay Danjaq \$350 000.

Initially, Derek Coyte Ltd, the product placement firm for James Bond movies at the time, had wanted Marlboro for License to Kill. Philip Morris had rejected this as "the wrong 'fit' and image for Marlboro". Leo Burnett's London division decided that Lark cigarettes were more consistent with "the spy theme of the movie". ${ }^{24}$ This type of "fitting" specific products to certain movies and characters was a common aspect of product placement by the tobacco companies. Another example was included in a 27 June 1990 consulting agreement between RJ Reynolds International and Rogers and Cowan International where a handwritten addition is added to the contract stating: "RJR will provide written guidelines, based upon brand strategies, for the selection of films, characters and situations." ${ }^{25}$

\section{American Tobacco}

The third major company involved in tobacco product placement was the American Tobacco Company (ATC). In an internal memo dated 11 October 1982 to WJ Moore, the company's advertising director, John McGinn, ATC's product manager, expresses his concern over "how active the competition is in promoting their products in major films". He then goes on to recommend that they contract with Cliff McMullen of Unique Product Placements (UPP) of North Hollywood. ${ }^{26}$ McGinn reports that McMullen's activities will include providing "movie memos which give the particulars of the film including potential product exposure" and, if ATC agrees, arranging "for placement of products" ${ }^{26}$ During filming he will visit the set "to assure our product is being used and used properly". Under contract, UPP will place ATC products in an estimated 25 feature films per year for an annual fee of $\$ 25000 .^{26}$

On 28 October 1982, McMullen wrote to ATC and provided a list of what his product needs would be in addition to tobacco. His comments and list are quite instructive in providing a broad picture of the promotion opportunities involved in product placement. He notes: "many times we can get a display, a sign, a $\mathrm{T}$ shirt, a logo, etc inserted into a positive scene, even when the product may not be used in the movie. This gives us a real-life environment into which your name is used." ${ }^{27}$ Among the items he requests are signs (all sizes up to billboards), posters and banners, ashtrays, napkins, lighters, T shirts, jackets, caps, trucks (from small vans up to 18 wheelers), antique signs and displays, counter cards or trays, and period products. Almost anything that might feature a particular tobacco brand was an opportunity in waiting for product promotion. Four years later, McGinn reported to
Moore that UPP had been successful in placing ATC products in approximately 30 major motion pictures per year and recommended an annual payment of $\$ 40000{ }^{28}$ Moore reports: "Our participation has varied from simple product use between principals in the film to the spectacular opening in Beverly Hills Cop . . . which provides us exposure for our Lucky and Pall Mall brands." ${ }^{28}$ The opening scene of Beverly Hills Cop provides an excellent example of tobacco product placement in film. Eddie Murphy, working as an undercover cop, encourages a pair of criminals to buy a truckload of contraband Lucky Strikes and Pall Mall cigarettes. As the scene progresses, the camera pans across the boxes of Lucky Strikes and Pall Malls over 25 times during a five minute time period. At one point, Eddie Murphy breaks out a pack of cigarettes from a box and notes "These are very popular cigarettes with the children" (fig 1).

\section{Brown and Williamson}

Brown and Williamson (B\&W) contracted with the product placement firm AFP and worked directly with the president of the firm, Robert Kovoloff, between 1979 and 1984. AFP arranged a contract on behalf of B\&W to pay $\$ 500000$ to Sylvester Stallone in which he guaranteed "I will use Brown and Williamson tobacco products in no less than five feature films". ${ }^{29}$

An audit of AFP carried out in the fall of 1983 by DR Scott, B\&W's director of auditing, raised serious questions about the company's relationship with Kovoloff. Scott noted in a memo dated 26 October 1983 that B\&W had paid Kovoloff \$965 500 for movie placements of which $\$ 575000$ was for movies not yet released. Based on the findings of the audit he concluded: "the Company's internal controls and procedures for documenting intended movie placements and performances have not been and are not currently adequate." ${ }^{\prime 30}$ One specific concern was that AFP kept a "second set of books" concerning money to be spent on "special placements". AFP reported that payments were distributed "based upon instructions of the movie producer" and that the "producers normally do not want payments in the form of checks to individuals. They prefer cash, jewelry, cars, etc". ${ }^{31}$ A second concern was that there were no agreements in writing. There were no records "describing how and for what duration B\&W products and advertising will be utilized in special movie placements contracted, and there is generally nothing in writing concerning payments to third parties". ${ }^{31}$ Finally, there were no procedures in place at B\&W to assure "that AFP has actually been placing our products in movies". ${ }^{31}$ For example, in the movie Tempest, Scott reported seeing "what appeared to be a pack of Barclay on the screen for a second. The word Barclay could not be seen" ${ }^{31}$ For this one second appearance of Barclay, AFP had supposedly paid $\$ 70000$.

As critical as the audit was, an unsigned, internal "review of corporate policies regarding movie placements" still argued for the value of product placement. ${ }^{31}$ The review stated that "placement of signage/product in movies allows BWT to receive extensive exposure at minimum cost". ${ }^{32}$ Another advantage was "Association with a specific star's image can enhance/build a brands personality-more than traditional media". ${ }^{32}$ On the negative side, the memo listed the danger of adverse publicity, the fear that the government might require a warning label, and that unrecorded payments "could be construed as aiding and abetting tax evasion".32 The recommendation was to continue with the programme. "Adverse publicity would be aimed at the whole industry, not just BWT." Competitors were moving "heavily" into the market and "would have a significant edge" if B\&W stopped pursuing product placement. ${ }^{32}$ A proposed new programme would involve three elements. B\&W resources would be concentrated "on special movie placements where a star actually smokes our brand and where our presence in the movie is more 
apparent". For these efforts B\&W was prepared "to pay \$100M-\$250M/movie depending on star involvement and quality of movie" ${ }^{\prime 32}$ (M represents $\$ 1000$ ). There was to be a written contract directly with the studio for each movie specifying how brands would be treated. Finally, AFP would be continued to be retained at $\$ 120 \mathrm{M}$ per year to represent B\&W. In addition, BEW would pay AFP “a commission of \$20M for each special placement with a major star" ${ }^{32}$

The proposal was either not implemented or very short lived. An internal memo from JM Coleman, B\&W's vice president of brand management, to NV Domantay, vice president of domestic advertising, on 2 February 1984, followed up on an 11 January 1984 decision to terminate B\&W's relationship with AFP. Coleman had met with AFP to discuss the termination and as of the meeting "BWT products were not to be placed in any films, including those we already paid for if they can be edited out". ${ }^{33}$ The new corporate policy was that there would be no further B\&W products placed in movies. AFP was to "negotiate with Stallone or try to sell his contract". ${ }^{33}$ A later handwritten memo from Domantay reported that he had no problem with paying Stallone $\$ 110 \mathrm{M}$ to get out of the B\&W contract assuming "I can have a signed release form from Stallone himself". ${ }^{34}$ [original emphasis] No record was found that $\mathrm{B} \& \mathrm{~W}$ received a signed release form or that a final payment was made.

While B\&W was pursuing product placement opportunities, it also embarked on an ambitious programme to advertise in movie theatres using trailers run during the movie previews. A memo dated 15 December 1982 from RA Blott in Cinema Advertising to BL McCafferty in Brand Management notes: "Cinema advertising is a legitimate medium for cigarettes and we should not be shy in our efforts to develop effective advertising. The product should be the star or hero and in front at all times." ${ }^{35}$ Each brand was to design a proposed campaign. The Kool spot was "totally homegrown and American in character". It was "upbeat and hip", taking on "the dimensions of an MTV video", and likely to be "memorable to a younger audience" ${ }^{36}$ The concern was that the use of the spot at showings of films such as Jedi Knights and Superman III during the summer months might be "misconstrued as an outright approach to underage audiences" ${ }^{36}$

In the end, neither Jedi Knights nor Superman led to the downfall of B\&W's cinema advertising programme. It was the Disney cartoon Snow White. ${ }^{37}$ By mid summer 1983, cigarette ads were running in 3000 theatres. On 22 July, J Ahearn, B\&W's manager of corporate communications, reported in a note to corporate affairs that he had received a press query from a reporter asking about a Kool cinema advertisement that had "recently been shown in a Boston Theater with the "G" rated "Snow White" Disney film". ${ }^{38}$ The grass roots non-smokers' rights group, Massachusetts Group Against Smoke Pollution (GASP), protested this advertising effort. ${ }^{37}$ The potential for negative reaction was well understood by corporate affairs. NV Domantay reports in a follow up memo to Dr Hughes, B\&W's senior vice president, on 4 August 1983: "if this becomes a firestorm, it could impact the acceptance rate of our ads among theater owners. Worse yet, it could get Washington into the act." ${ }^{\prime 39} \mathrm{~B} \& \mathrm{~W}^{\prime} \mathrm{s}$ worst fear was quickly realised. In September, Action for Children's Television filed a complaint with the Federal Trade Commission (FTC) urging that tobacco advertising be blocked from being shown at " $\mathrm{G}$ " and "PG" movies. FTC in turn wrote to B\&W noting from Action for Children's Television's complaint that B\&W was engaging in "deceptive and unfair trade practices" and requesting extensive documentation on the cinema advertising programme. ${ }^{40}$

The "firestorm" surrounding the Snow White incident, the FTC inquiry, and a growing concern about the programme's costs, effectiveness, and controls led B\&W to question the value of cinema advertising in much the same way it was questioning product placement. On 23 February 1984, CNN called B\&W seeking information on cinema advertising and was informed that the decision had been made to discontinue the programme and that "This decision was made at the highest levels of our company". ${ }^{41}$

\section{Product placement initiated by the entertainment industry}

Production companies also approached the tobacco industry offering to promote tobacco in return for payment. An example was an effort made by Twentieth Century Fox Licensing and Merchandising Corporation. In a letter to JR Ave, executive vice president for Lorillard on 1 November 1984, Hubert Nelson of Fox stated that Fox was seeking "joint marketing efforts of mutual benefit" with a tobacco company and that Fox could offer "ample opportunities for appropriate placement of your product".$^{42}$ Under the relationship, Lorillard would have exclusivity for cigarette product placement and receive the movie script in advance with an overview of how the product or signage would be used. For "ordinary useage" Lorillard would pay \$20000 upon release of the film and Lorillard's satisfaction. Lorillard declined to participate because it had "a belief motion pictures may not be an appropriate vehicle for the promotion of our products". ${ }^{43}$

Philip Morris was more open to the offer and met with Hugh Nelson to explore a possible arrangement with Fox. Nelson then spelled out the proposed arrangement to Frank Saunders, vice president for corporate relations and communications at Philip Morris, in a letter dated 16 January $1984{ }^{44}$ Fox was seeking an 18 month agreement in which Fox "would guarantee you product placement in the final version of four feature films during the 18 month period. We would offer your products exclusivity for the period of the contract. You would have script approval for the placement of your products." ${ }^{\prime 4}$ Added benefits of "collateral publicity opportunities involving Fox stars" and the arrangement of "appropriate screenings for you and your wholesalers" were to be thrown in once the contract was signed. ${ }^{44}$ The price was $\$ 100000$; Philip Morris turned down the offer. ${ }^{45}$

\section{Increasing public scrutiny}

By the late 1980s paid product placement and other tobacco industry activities relating to the entertainment industry were becoming a public issue. Health oriented groups had begun monitoring tobacco use and brand identification in movies and were calling for action. In a letter to the editor of Phillip Morris's PM Journal, Ronald M Davis from the American Medical Association (AMA) Board of Trustees reported that the AMA was calling for a ban of tobacco use and brand names in movies when "this occurs as the result of payment by tobacco companies or their advertising agencies" ${ }^{46}$ Stop Teenage Addiction to Tobacco (STAT) included a "Reward for Moviegoers" ad in a 1990 edition of its newsletter, The Tobacco and Youth Reporter. STAT would provide a free poster to anyone "who brings to our attention movies in which brand specific cigarette packages, advertisements, or other references appear" ${ }^{47}$ Earlier editions of the newsletter had already identified "more than two dozen" movies that the organisation felt contained paid tobacco advertising. ${ }^{48}$ Public concern led to three government efforts: a Congressional Hearing in front of Thomas Luken's (Democrat, Ohio) Subcommittee on Transportation, Tourism, and Hazardous Materials, an inquiry by the FTC, $^{49-51}$ and a petition to the Federal Communications Commission. $^{52}$

Philip Morris hired The Dolphin Group, a public relations firm, to organise opposition to any possible legislation in Congress. ${ }^{15}$ (The Dolphin Group later played an important role in Philip Morris' attempts to stop or overturn clean indoor air laws in California. ${ }^{534}$ ) Philip Morris wanted Dolphin to "try and garner motion picture industry support to testify against the Luken Bill, if it becomes necessary. [Fred Karger of 
Dolphin] is looking for directors, producers, film commission representatives, etc, to express opposition to the censorship a bill like Luken's would impose on the creative ability of the motion picture industry." ${ }^{15}$ The strategy would be to hide the economic interests of the tobacco and entertainment industries behind the rallying cry of opposing censorship.

Joe Tye, president of STAT, had sent a detailed letter to Congressman Luken dated 11 July 1989 outlining brand exposure in several movies, including Camel use in the movie Two of a Kind starring John Travolta and Olivia Newton-John. According to Tye: "One of God's messengers drives a bus with a huge Camel ad on the side. In a masterful association of forbidden fruits, the devil tempts the angels with scantily clad young ladies with the Camel ad serving as a conspicuous backdrop. In the final scene, God's messenger asks Travolta for a cigarette."48 Luken responded by writing to the companies for an explanation. RJR's response to Luken on Two of a Kind was "to the best of our knowledge, neither the Company or Rogers and Cowan was asked to provide product or promotional materials". 55

The facts suggest otherwise. In its 7 September 1983 report to RJR, Rogers and Cowan noted they had been successful in placing Camel cigarettes in Two of a Kind (titled A Second Chance at the time): "We are pleased to report the excellent brand identification for Camel Filters will occur in this upcoming comedy motion picture," William Cowan enthused. "In fact, a pack of these cigarettes will be the major focus of an entire scene in which John Travolta's character steals a pack of Camel Filters for the angel, another major character in the film." ${ }^{56}$

RJR provided minimal information about the aggressive efforts of Rogers and Cowan to place RJR products over the previous eight years. In its initial response to Luken, Wayne Juchats of RJR stated: "From time to time the Company, upon request from a movie producer, will provide free product and/or promotional materials (not including billboards) for a film production.. ${ }^{57}$ Despite the detailed reports at RJR from Rogers and Cowan going back to 1980, Juchats argues: “To go back prior to 1982, as requested in your letter would be a most difficult task, would require us to locate and interview former employees, and even if undertaken, undoubtedly not result in our being able to provide complete answers to many of the questions solicited in your January 25 th letter. Under these circumstances, we believe that little would be gained by a time-consuming examination of the pre-1982 period.".57

Other tobacco companies were equally reluctant to come forth with information on their activities. A briefing paper put together by the companies for Charles Whitley of the Tobacco Institute on 7 July 1989 in preparation for his testimony before the Luken Committee states: "when-and only when-approached by filmmakers, tobacco companies have occasionally agreed to donate free cigarettes and signs for movies." ${ }^{58}$ The paper also claims: "Tobacco companies do not encourage smoking scenes in movies. They never request changes, and have never been given the right to make changes in any film." 58

In a summary prepared by Charles Pomerance for use in responding to Luken, Phillip Morris claimed existing policy did "not pay any company for product placement" and did not "seek product placement". ${ }^{59}$ It had, in fact, paid for product placement in both Superman II and License to Kill.

B\&W reported to Luken that it did "not know of any situation in which it caused a smoking scene to appear in a movie or television program since $1979{ }^{\prime \prime}{ }^{60} \mathrm{~B} \& \mathrm{~W}$ did not mention its four year history of working with AFP. There was no mention of the Stallone contract or the "special placement" fund Kovoloff supposedly maintained to encourage the use of B\&W products by prominent actors.

\section{The industry adapts}

What impact did the 1989 Congressional Hearings have on the efforts of the product placement firms and the cigarette manufacturers? The response was similar to that in the past when other advertising practices became controversial and increased the likelihood of regulation. The cigarette companies claimed to solve the problem by modifying their voluntary Cigarette Advertising and Promotion Code. ${ }^{61}$ In 1990, they added: "No payment shall be made by any cigarette manufacturer or any agent thereof for the placement of any cigarettes, cigarette packages, or cigarette advertisements as a prop in any movie produced for viewing by the general public." ${ }^{62}$ They could and would continue to provide free product, signs and other props.

What impact did this have on aggressive efforts by the tobacco industry to secure "free" tobacco product placements in movies? A memo to John Dean III of RJR from Frank Devaney of Rogers and Cowan on 12 April 1990 clearly demonstrates that the firm was still very active in the area:

"Today, the presence of cigarettes and smoking situations are considered a vital part of our program. Subliminal reminders are still used. Such things as providing merchandise with brand identification for studio based golf tournaments, prizes for studio picnics, other social gatherings and cast and crew jackets are still effective toward this goal.

\begin{abstract}
"The placement activities continue, but today we are very restrictive as to the story content, the potential audience and other factors that do not subject our placements to negative response, and continue (to support) the acceptable smoking (i.e. smoking by adults) which is still a regular part of many viewers lives.

"We have also developed a strong sampling pro-
gram, which now provides 188 industry leaders
and stars with their favorite brands each month.
This group provides support to the intention of
the program to continue smoking within the
industry and within the productions they
influence" ${ }^{3}$ [emphasis added].
\end{abstract}

Rogers and Cowan was doing everything possible to maintain a favourable image for RJR within the entertainment industry, place products when they would not lead to negative response, and keep Hollywood hooked on tobacco.

Clifford McMullen of UPP was also still active in the early 1990s. An exchange between W Degenhardt, ATC's assistant to the media director, to his boss JJ Mellet is worth reporting. UPP had brought to ATC's attention that Pathe Productions was producing Harley Davidson and the Marlboro Man, and wanted to change the movie's name to Harley Davidson and the Lucky Strike Man. Under this scenario, "Don Johnson would play the 'Lucky Strike Man' and would use Lucky as his nickname throughout the movie". Degenhardt recommended accommodating the request depending on "legal's review and discussion" ${ }^{64}$ In the end, the movie came out as Harley Davidson and the Marlboro Man.

Another memo from McMullen to Geoff Maresca at ATC on 5 September 1991 addressed concern over what the "competition" was doing. Noting that he had talked with Rogers and Cowan representing RJR and Baldwin/Varela Associates representing Philip Morris, he stated: "Their position as of this day is 'business as usual' [original emphasis]. They have received no new instructions from their clients and neither of them is aware of any decisions to discontinue their efforts in the film community." ${ }^{\prime 5}$ But ATC was backing away from "business as usual". The 1991 contract renewal for UPP would state that the company's role would "be reactive rather than proactive on 
American tobacco's behalf" ${ }^{66}$ UPP would continue to be ATC's advocate in the film community, keep them abreast of film trends related to tobacco issues, and keep an eye on Phillip Morris's and RJR's Hollywood efforts. The reactive role was emphasised in UPP's 1992 contract where UPP was "to field requests from film companies to use products", and was "not to approach filmmakers to encourage them to use cigarettes as props in films or to portray persons in films smoking cigarettes".67

\section{The international scene}

There was greater flexibility on the international scene. As early as 1981, Rogers and Cowan had reported to RJR that it "was very strong in Europe ... and could also expand our work with filmmakers in various European capitals" ${ }^{25}$ A draft consulting agreement between RJR and Rogers and Cowan International dated 27 June 1990 shows an aggressive approach to product placement internationally. The stated purpose of contract was to "fulfill demand for the use of RJR products, advertising or signage as props, in adult smoking scenes in European feature films" ${ }^{25}$ More specifically, it was to assure that RJR products were used in "adult smoking scenes by actors and in situations, which create visibility for RJR products and show them in a positive manner compatible with RJR's overall marketing strategy and plans for such products".$^{25}$

The "consultant was to avoid supplying RJR products for use in smoking scenes that primarily appeal to youth or students or depict youth or students or persons under 21 years as smokers". ${ }^{25}$ Interestingly, the word "directly" had been penciled in between the words "avoid" and "supplying" to change the contract to read "avoid directly supplying". This change may suggest that "indirect" placement was an acceptable alternative. No RJR product was to be supplied "for use in scenes which feature characters or story lines which portray the brand in a negative manner, for example, smoking by violent criminals, smoking by dying persons, etc" ${ }^{25}$ There was to be no implication that people died from smoking RJR products.

The consultant's fees were directly tied to his success in promoting RJR. During 1991 the consultant's fee was to be $£ 7000$ per month but RJR would be released from making its fourth quarter payment ( $£ 21000)$ unless RJR products were "easily recognizable in at least 12 or more feature films produced during calendar 1991". ${ }^{25}$ This arrangement hardly implied a passive response for "fulfilling demand for use of RJR products" in European films.

Another 1990 agreement between RJR International and Rogers and Cowan made it clear that continued product placement in films was a direct response to increasing restrictions on traditional advertising and that this placement could be accomplished without direct cash payments to directors or producers; it said:

\section{"For a monthly fee, Rogers and Cowan will arrange to obtain placement of RJR products, packages, and adver- tising in films through smoking scenes in which actors are shown smoking RJR brands and other scenes which cre- ate visibility. Film placement of RJR brands will create favorable imagery and presence as advertising restric- tions intensify. Although RJR will pay Rogers and Cowan for their services in fulfilling demand for our products in films, no cash payment will be made by Rogers and Cowan or RJRTI to directors or producers for film placement ${ }^{\prime 68}$ [emphasis added].}

It is interesting to note that the contract does not prohibit payment to actors, property masters, and others who can influence the use of tobacco in films. Payment in kind is also not prohibited.
A 1992 contract showed that Rogers and Cowan International continued its efforts through $1993 .^{25}$

\section{Cigar product placement}

Paid cigar product placement became an issue in the mid 1990s. The 1990 voluntary code that was agreed to by the major cigarette manufacturers did not include cigars, nor did the federal legislation ending cigarette advertising on television in the 1970s. The FTC report to Congress on cigar sales in 1996 and 1997 notes: "Expenditures on celebrity endorsements and appearances, and payment for product placements in movies and television more than doubled between 1996 and $1997^{\prime \prime 69}$ [emphasis added].

The cigar industry's focus on exploiting the entertainment industry is the result of a well thought out campaign. ${ }^{70}$ Starting in the 1980s several cigar manufactures joined together under the Cigar Association of America to recast the cigar's image. No longer was it to be a symbol of "smoke-filled rooms where nefarious schemes are hatched". ${ }^{71}$ Instead a massive public relations campaign would be mounted to position the lowly cigars as status symbols, "associating them with women and celebrations and highlighting successful cigar smokers as role models" ${ }^{71}$ The majority of the role models were to be Hollywood personalities and paid product placement would help with the casting. General Cigar Company contracted with the product placement firm of Keppler Entertainment Inc for $\$ 27000$ to place its products on such popular TV shows as Friends, Baywatch, Mad About You, Spin City, Suddenly Susan, and Third Rock From the Sun. ${ }^{71}$ These programmes are particularly popular with young audiences.

Another means of obtaining brand exposure was through providing entertainers with free products. Actor Joe Pantoliano is open about his solicitation of cigar donations for use in movies and television programmes. In a 1996 Cigar Aficionado article he states: "You know, I'd do a movie, I'd call Davidoff and say 'Listen, I' $m$ doing a movie, I want to smoke your cigars in the movie."' ${ }^{70} \mathrm{He}$ also reports soliciting donations of Fuentes Cigars for the 1995 movie Steal Big, Steal Little and El Credito cigars for the movie Bad Boys. For EZ Streets, a CBS pilot, he chose "Don Carlos No. IIIs". In the highly popular 1999 movie Matrix, we find Pantoliano's character, Cypher, willing to double cross his buddies for the "good life" epitomised by an expensive meal and a cigar. Cigar Aficionado notes: "Pantoliano's appreciation and knowledge of cigars, and his use of them as props in films, has helped him create a wonderful world" [emphasis added].

In 1998, the Cigar Association of America amended its placement policy. Parroting the cigarette industry, the association's policy now states: "A cigar manufacturer should not subsidize the use of cigars in movies or television productions through paid or donated cigar placements or otherwise.".69

\section{DISCUSSION}

Tobacco use in movies, which was falling through the 1970s and 1980s, increased significantly after $1990 .{ }^{72-78}$ While there may be various reasons for this trend, the extensive groundwork laid by the tobacco industry in the 1980s and early 1990s certainly played a role. Publicly available documentation proving paid cigarette product placement from the mid 1990s on is limited. Brand use depiction in films, however, has been tracked. While such depiction does not prove product placement activities by the tobacco industry, extensive brand use depiction suggests that more may be involved than mere coincidence.

The tobacco industry denies that they are continuing to engage in product placement, but they denied doing it in the 1980s, when we know they were doing it. The Master Settlement Agreement does not preclude giving out free cigarettes or sponsoring events, such as film festivals, which are important to people in the entertainment industry. Given the 
increase in smoking in the movies and the historical relationship between tobacco and Hollywood, it is hard to believe that the tobacco industry has stopped encouraging smoking in movies. This problem is particularly difficult given the industry's long tradition of covert action in not only its relationship with Hollywood, but also in science, politics, and elsewhere.

The Thumbs Up! Thumbs Down! Project (TUTD) of the American Lung Association of Sacramento-Emigrant Trails tracked brand use in the top 50 films annually between 1991 and 2000. Its data suggest that RJR and B\&W limited brand placement activities during the 1990s: of the 52 brand use appearances recorded, six were from B\&W and five from RJR. Forty, or $77 \%$, of the exposures were Philip Morris products and 35 of these were Marlboro. ${ }^{79}$ Similarly, Sargent and colleagues $^{7}$ reviewed the top grossing 25 films each year between 1988 and 1997 and found brand appearances in 28\% of the films reviewed. Interestingly, they found no significant difference between the number of brand exposures in the periods before and after the tobacco industry adopted its voluntary restrictions on product placement. They also found little difference in brand exposure between " $\mathrm{R}$ " and "PG" rated movies. Brand exposure through actor use increased from $1 \%$ of the films before the industry's voluntary restrictions on product placement to $11 \%$ afterwards, with Marlboros dominating the brand identification.

Shields and colleagues ${ }^{80}$ carried out 54 qualitative in-depth interviews during 1997 and 1998 from a convenience sample of writers, actors, producers, directors studio executives and other's involved in the film industry to determine how the entertainment industry understands tobacco portrayal. When asked directly whether tobacco product placement existed in movies, many of the interviewees said they "thought it occurred" although none claimed to know of any specific placements. The feeling was that product placement did not drive tobacco use in movies but "if smoking was to be depicted, then either placement deals or product donation might play a role, particularly among independent film producers".

The settlement of the Minnesota lawsuit against the tobacco industry and the Master Settlement Agreement of 1998 between the tobacco companies and most US state attorneys general provides legal reinforcement to the cigarette manufacturer's voluntary "ban" on paid product placement. Section III, subsection (e) states, "No Participating Manufacturer may ... make or cause to be made, any payment or other consideration to any other person or entity to use, display, make reference to or use as a prop any Tobacco Product, Tobacco Product package, advertisement for a Tobacco Product or any other item baring a brand name in any motion picture, television show, theatrical production or other live performance, live or recorded performance of music, commercial film or video, or video game . ..". ${ }^{81}$ (The cigar companies are not a party to this agreement.) As of January 2002, no action has been taken against any cigarette company for violating this agreement.

This may reflect the fact that the tobacco industry is honouring its terms. It may also reflect the industry's skill in acting secretly through intermediaries to promote tobacco use in films, much as it has done to generate controversy about the evidence that active and passive smoking cause disease ${ }^{37}$ or to organise opposition to tobacco control measures. ${ }^{54}$ The fact that the tobacco companies did not disclose the full scope of their efforts to encourage smoking in the movies when the US Congress was investigating the issue in 1989 does not give credibility to the denials of product placement throughout the 1990 s and beyond.

Placement being conducted through foreign subsidiaries, which has existed for at least 20 years, could be continuing. In addition, as noted explicitly in RJR International's 1991 agreement with Rogers and Cowan ${ }^{68}$ it is possible to achieve purposeful product placement without direct cash payments to producers and directors. Thus efforts to locate cash payments for using tobacco in films may be searching for the wrong stimulus.

Whether the presence of tobacco is due to tobacco industry activities or not, however, the effect on promoting tobacco is the same. Many of the messages that tobacco, as a prop, is used to convey-rebellion, independence, sexiness, wealth, power and celebration-are images the tobacco industry has created to sell its products. ${ }^{73}$ The TUTD found that $48 \%$ of the 1999-2000 movies they reviewed carried such messages. ${ }^{79}$ Tobacco use is rarely presented as a cause of death and suffering, or an activity more and more concentrated in lower socioeconomic strata. ${ }^{73} 76$ To the degree that directors, performers, and writers accept and repeat images created by the tobacco industry, they continue to provide powerful, "subliminal" messages to young people that tobacco use is an acceptable, even highly desirable, activity. It is also important to note that whether tobacco is used by heroes or villains, it still promotes tobacco use. ${ }^{45}$

This promotional activity is particularly important from an international perspective. Many countries outside the USA have ended or severely restricted traditional cigarette advertising, making US (and other) motion pictures and television programmes important channels-in some cases the most important channel-for promoting tobacco use among young people. The US entertainment media also reinforces the tobacco industry's theme, particularly in developing countries, that smoking is a way to emulate America.

Roger and Cowan's effort to encourage personal tobacco use in Hollywood was an effective-and inexpensive-technique to increase tobacco use in movies. The actor that smokes at home is more likely to smoke in public and light up in movies. Directors and writers can be expected to perform in a similar manner. Conversely, the director who does not tolerate secondhand smoke can be expected to be less tolerant of tobacco use on the set. The actor who does not smoke in his or her personal life will be more reluctant to smoke on screen. The writer who does not smoke may be less likely to have his characters use tobacco. A carefully designed campaign by the public health community to encourage Hollywood to kick the habit may be an effective strategy available to reduce tobacco use in movies.

There are a variety of policy based strategies being applied by public health advocates throughout the world. These include working with the entertainment community to convince them to change tobacco use patterns voluntarily, developing standards for "responsible" depiction of tobacco, initiating efforts to make it economically disadvantageous to include smoking (such as by requiring an "R" rating, which decreases potential ticket sales), placing anti-smoking advertisements before films containing smoking, ${ }^{4}$ and instituting policies/certification to assure that no one connected with making the film received anything in exchange for promoting tobacco.

\section{Conclusion}

The tobacco industry has a long history of working to influence Hollywood. The power of film to promote the "social acceptability" and desirability of tobacco use, particularly among young people, is a continuing inducement for the tobacco industry to utilise this medium. The increase in tobacco use and the continuing appearance of specific brands in movies since 1990 may reflect continuing activities by the tobacco industry, despite the industry's voluntary restrictions on such practices. It may be that, as with provisions of the industry's voluntary advertising code that nominally restricts print marketing to children, ${ }^{82}$ the industry finds ways around its own rules.

Until something is done to reduce and eliminate protobacco images on film, motion pictures will remain one of the 


\section{What this paper adds}

After falling throughout the 1960s through the 1980s, tobacco use in films increased rapidly during the 1990s. Exposure to tobacco use in films is associated with increased smoking by youth and an increase in favourable attitudes towards tobacco use.

This paper uses previously secret tobacco industry documents to describe the development of a close relationship between the tobacco industry and the entertainment industry, and illustrates how both industries appreciated the value of promoting tobacco products through use in the entertainment media. It illustrates the techniques used by the film industry to solicit involvement by the tobacco industry and vice versa.

most powerful forces in the world promoting tobacco and serving the tobacco industry's financial interests.

\section{ACKNOWLEDGEMENTS}

We thank Teresa Martin, Mira Dougherty-Johnson, MLS, and Celia White, MLS for research assistance, and James Sargent for providing the stills in fig 1.This project was supported by funds received from the Tobacco Tax Health Protection Act of 1988 - Proposition 99, under Grant Number 99-85068 with the California Department of Public Health Services, Tobacco Control Section and National Cancer Institute Grant CA-87472.

\section{Authors' affiliations}

C Mekemson, American Lung Association of Sacramento Emigrant-Trails, STARS Project, Sacramento, California, USA; staff@saclung.org

S A Glantz, Institute for Health Policy Studies and Cardiovascular Research Institute, University of California, San Francisco, San Francisco, California, USA

\section{REFERENCES}

1 Chapman S, Davis R. Tobacco use in films: is it a problem? Tobacco Control 1997;6:269-71.

2 Distefan J, Gilpin E, Sargent J, et al. Do movie stars encourage adolescents to start smoking? Evidence from California. Prev Med 1999;28:1-11.

3 Pechmann C, Shih C-F. How smoking in movies and anti-smoking ads before movies may affect teenagers' perceptions of peers who smoke. Irvine, California: Graduate School of Management, University of California, Irvine, 1996

4 Pechmann C, Shih C. Smoking in movies and antismoking advertisments before movies: effects on youth. J Marketing 1999:63:1-13.

5 Pechmann C. A comparison of health communication models: risk learning versus sterotype priming. Media Psychology 2001;3:189-210.

6 Tickle JJ, Sargent JD, Dalton MA, et al. Favourite movie stars, their tobacco use in contemporary movies, and its association with adolescent smoking. Tobacco Control 2001;10:16-22.

7 Sargent J, Tickle J, Beach M, et al. Brand appearances in contemporary cinema films and contribution to global marketing of cigarettes. Lancet 2001;357:29-32.

8 Sargent J, Beach $M$, Dalton $M$, et al. Is viewing tobacco use in motion pictures associated with trying smoking? BM (in press).

9 Richards R, UNK. We are about to go into production with the motion picture, "Run Sheep Run", A suspense, thriller, set in Los Angeles. RJ Reynolds; August 25, 1972. Access date: March 26, 2001. Bates No. 500201423-1424. URL: http://www.rirtdocs.com/

10 Breidenbrach K. [Letter from Kelly Breidenbach of Baldwin Varela to Walter McDonald of Liggett \& Meyers]. In: Lorillard. p. 91753669/3670.

11 Christie D. Proposed sponsorship of the film 'Eight Men Out'. Liggett \& Meyers; September 21, 1987. Access date: March 26, 2001. Bates No. 2023203794. URL: http://www.pmdocs.com/ getallimg. asp? $D O C I D=2023203794$

12 Kelly Weedon Shute Advertising. Philip Morris cigarette marketing - a new perspective. Kelly Weedon Shute Advertising; November 1989. Access date: March 28, 2001. Bates No. 2501057693-7719. URL: http://www.pmdocs.com/getallimg.asp?DOCID=2501057693-7719.

13 Associated Film Promotions. Recall and recognition of commercial products in motion pictures. Brown \& Williamson; September 1, 1981 Access date: March 27, 2001. Bates No. 682158296-8307. URL: http://www.bwdocs.aalatg.com/public.asp.

14 Maxwell H. Draft of speech for Hamish Maxwell Maxwell, marketing meeting, 000624. Phillip Morris; 24 June 1983, 1983 www pmdocs.com. Access date: October 13, 2001. Bates No. $2021285680-5697$ URL: http://www.pmdocs.com/ getimg. asp?.pgno $=0 \&$ start $=0 \&$ if $=$ avpid $x \&$ bool $=2021285680 \&$ docid $=20$ $21285680 / 5697$ \&docnum $=1$ \&summary $=0$ \&sel 1 .

15 Devany F. I have been contacted By Fred Karger of The Dolphin Group Public Relations Company, regarding his client Philip Morris. R.J. Reynolds; June 23, 1989. Access date: March 28, 2001. Bates No. 515687482 -7482. URL: http://www.rirtdocs.com/rirtdocs/frames.html.

16 Cowan W. I'm sorry we didn't get to see each other last week when I was on my way back from Puerto Rico, but your secretary said you were out of town. R.J. Reynolds; May 4, 1981: Access date: March 27, 2001 Bates No. 503579240 -9244. URL: http://www.rirtdocs.com/.

17 Cowan W. Report \#5. Rogers \& Cowan; October 21, 1980. Access date: March 30, 2001. Bates No. $503579311-9317$. URL: http://rirtdocs.com/.

18 Cowan W. Activity report - R. J. Reynolds. Rogers \& Cowan; November 9, 1982: Access date: March 30, 2001. Bates No. 503579586-9591. URL: http://rirtdocs.com/.

19 Cowan W. Activity report. R.J. Reynolds; August 26, 1981: Access date: March 27, 2001. Bates No. 503579378-9381. URL: http://www.rirtdocs.com/

20 Devaney F. Activity report - R. J. Reynolds. Rogers \& Cowan, Inc. September 3, 1982: Access date: March 27, 2001. Bates No. 503579592-9594 URL: http://www.rirtdocs.com/.

21 Philip Morris. List by year of movies for which product was supplied in connection with Charles Pomerantz and Andrew Varela. Philip Morris; March 1, 1989: Access date: March 30, 2001. Bates No. 2025863645-3659. URL: http://www.pmdocs.com/ getallimg.asp?DOCID=2025863645/3659.

22 Spengler P. 'Superman II' - The Movie. Dovemead Limited; October 18 1979: Access date: March 27, 2001. Bates No. $2026120960-0962$. URL: http://www.pmdocs.com/getallimg.asp?DOCID=2026120960/ 0962.

23 Danjaq S. [Letter from to Danjaq S.A. to Leo Burnett-Kyodo Company Ltd.]. Leo Burnett-Kyodo Company Ltd. Advertising; September 14, 1988: Access date: March 27, 2001. Bates No. 2026120963-0968. URL: http://www.pmdocs.com/getallimg.asp? DOCID=2026120963/0968.

24 None. [Brief overview of Philip Morris product placement in movies] Philip Morris; April 1, 1989: Access date: March 27, 2001. Bates No. 2022971746. URL: http://www.pmdocs.com/ getallimg.asp?DOCID $=2022971746$.

25 Rogers \& Cowan INTL RJR INTL. Consulting agreement. R. J. Reynolds; June 27, 1990. Access date: March 28, 2001. Bates No. 515997156 -7163. URL: http://www.rirtdocs.com/rirtdocs/frames.html.

26 McGinn J A. Unique Product Placement, Inc. American Tobacco Company; October 11, 1982. Access date: March 30, 2001. Bates No. 990723735. URL: http://www.bwdocs.aalatg.com.

27 McMullen CR. [Letter to J. McGinn, American Tobacco Company, regarding prop placement in movies]. Unique Product Placement; October 28, 1982. Access date: March 30, 2001. Bates No. 949002506-949002507. URL: http://www.bwdocs.aalatg.com.

28 McGinn JA. Unique Product Placement early contract renewal. American Tobacco Company; May 27, 1986. Access date: March 30, 2001. Bates No. 970313406 . URL: http://www.bwdocs.aalatg.com.

29 Stallone S. [Letter to B. Kovoloff guaranteeing use of B\&W tobacco products in five feature films]. April 28, 1983: Access date: March 30 2001. Bates No. 6850831 19. URL: http://www.bwdocs.aalatg.com.

30 Scott D. [Memo to N.V. Domantay detailing B\&W's relationship with Associated Film Promotions]. Brown \& Williamson; October 26, 1983 Access date: March 27, 2001. Bates No. 680517197. URL: http://www.bwdocs.aalatg.com

31 Chavers D. Audit survey - Associated Film Promotions. Brown \& Williamson; No date, No date. Bates No. $680118057-680118066$. URL: http://www.bwdocs.aalatg.com.

32 Brown \& Williamson. Product movie placement. Brown \& Williamson; No date, No date: Access date: March 27, 2001. Bates No. $680118048-680118052$. URL: http://www.bwdocs.aalatg.com

33 Coleman J. Review of termination discussions of 840111 . Brown \& Williamson; February 2, 1984. Access date: March 27, 2001. Bates No. 680517147-680517148. URL: http://www.bwdocs.aalatg.com.

34 Domantay N. No title. Brown \& Williamson; February 6, 1984. Access date: March 27, 2001. Bates No. 680517112 . URL: http://www. bwdocs.aalatg.com.

35 Blott RA. Cinema advertising. Brown \& Williamson Tobacco Corporation; December 15, 1982. Access date: March 30, 2001. Bates No. 514110795. URL: http://www.bwdocs.aalatg.com.

36 Brown \& Williamson. Cinema advertising - possibilities. Brown \& Williamson; No date, 1983: Access date: March 27, 2001. Bates No. 690132323. URL: http://www.bwdocs.aalatg.com.

37 Glantz SA, Barnes DE, Bero L, et al. The cigarette papers. Berkeley, California: University of California Press, 1996.

38 Ahearn JM. Press query. Brown \& Williamson; July 22, 1983. Access date: March 27, 2001. Bates No. 690132320. URL: http://www. bwdocs.aalatg.com.

39 Domantay NV. Cinema advertising. Brown \& Williamson Tobacco Corporation; August 4, 1983. Access date: March 30, 2001. Bates No. 170051201. URL: http://www.bwdocs.aalatg.com

40 Purzycki A. [Letter to E. Pepples regarding complaint from Action for Children's Television, Inc.]. Federal Trade Commission; November 8 , 1983. Access date: March 27, 2001. Bates No. 521000227-521000228. URL: http://www.bwdocs.aalatg.com

41 Mcalevey TP. Cinema advertising. Brown \& Williamson; February 23, 1984. Access date: March 27, 2001. Bates No. 690132392. URL: http://www.bwdocs.aalatg.com. 
42 Nelson H. [Letter to J.R. Ave regarding establishing a relationship with a major cigarette manufacturer]. Twentieth Century Fox Licensing and Merchandising Corporation; November 1, 1984. Access date: March 27, 2001. Bates No. $85621151 / 1152$. URL: http:// www.lorillarddocs.com/getallimg. asp? $i f=a v l i d x \& D O C I D=85621151 /$ 1152.

43 JRC. [Draft of letter to H.A. Nelson, Twentieth Century Fox Licensing and Merchandising Corporation]. Lorillard; November 9, 1984. Access date: March 27, 2001. Bates No. 85621150 . URL: http://

www.lorillarddocs.com/getallimg.asp? if=avlidx\&DOCID=85621 150

44 Nelson H. [Letter from Hubert Nelson of Twentieth Century-Fox Licensing Corporation to Frank Saunders of Phillip Morris]. Philip Morris; January 16, 1984. Access date: March 27, 2001. Bates No. 2021280495/ 0496. URL: http://www.pmdocs.com/ getallimg.asp?DOCID=2021280495/0496

45 Scott S. [PM memo from Stanley S. Scott to Frank A. Saunders]. Philip Morris; January 31, 1984. Access date: March 27, 2001. Bates No. 1005116180 . URL: http://www.pmdocs.com/ getallimg.asp?DOCID=1005116180.

46 Davis R, Richards K. PM notebook. Philip Morris; 1987, 1987. Access date: March 27, 2001. Bates No. 2022971809. URL: http://www.pmdocs.com/getallimg.asp? DOCID=2022971 809 .

47 STAT. STAT NEWS. Philip Morris; June, 1990. Access date: March 30 2001. Bates No. 2022972729-2732. URL: http://www.pmdocs.com/ getallimg.asp? DOCID=2022972729/2732. p. 4/2022972732

48 Tye JB. [Letter from Joe B. Tye of STAT to Representative Luken]. Tobacco Institute; July 16, 1989. Access date: March 30, 2001. Bates No. TIMN0024212-42 16. URL: http://www.tobaccoinstitute.com/ getallimg.asp?DOCID=TIMN0024212/4216\&if=avtidx.

49 Evans J. [Letter from Janet Evans of the Federal Trade Commission to Ehud Houminer of Philip Morris]. Philip Morris; January 26, 1990. Access date: March 27, 2001. Bates No. 2022971423-1431. URL: http://www.pmdocs.com/getallimg.asp? DOCID $=2022971424 / 1425$

50 Wilkenfeld J. Response of Philip Morris to cigarette access letters. Philip Morris; February 26, 1990. Access date: March 27, 2001. Bates No. 2022971609-1610. URL: http://www.pmdocs.com/ getallimg.asp?DOCID=2022971609/1610.

51 Chapman J, Jackson J. 900126 FTC request for information. Philip Morris; February 26, 1990. Access date: March 27, 2001. Bates No. 2022971843-1844. URL: http://www.pmdocs.com/ getallimg.asp?DOCID=2022971843/1844

52 Balasubramanian SK, Jacobsen M, Lubinski C, et al. Petition to amend the television sponsorship identification rules by rescinding the waiver of identification requirements with respect to feature motion picture films produced initially and primarily for theatre exhibition. Philip Morris: March 29, 1989. Access date: March 22, 2001. Bates No. 2024465051-5098. URL: http://www.pmdocs.com/ getallimg.asp?DOCID $=2024465051 / 5098$.

53 Macdonald H, Aguinaga S, Glantz, SA. The defeat of Philip Morris' 'California Uniform Tobacco Control Act'. Am J Public Health 1997;87: 1989-96.

54 Glantz S, Balbach E. Tobacco war: inside the California battles. Berkeley, California: University of California Press; 2000

55 Copenhaver WA. I very much appreciate the recent newspaper clippings you sent me relating to publicity on the west coast concerning Congressman Luken's activities. Womble, Carlyle, Sandridge \& Rice; R.J. Reynolds; March 22, 1989. Access date: April 3, 2001. Bates No. 515687505. URL: http://www.rirtdocs.com/rirtdocs/frames.html.

56 Rogers \& Cowan. Activity report - R.J. Reynolds. R.J. Reynolds; September 7, 1983 R.J. Reynolds. Access date: March 28, 2001. Bates No. 508454616-4620. URL: http://www.rirtdocs.com/rirtdocs/ frames.html.

57 Juchatz W. [Letter from Wayne Juchatz of RJR to Thomas Luken]. Tobacco Institute; February 28, 1989. Access date: March 30, 2001. Bates No. TIMN0203526-3527. URL: http://www.tobaccoinstitute.com/ getallimg.asp? $D O C I D=T I M N 0203526 / 3527 \&$ if=avtidx

58 None. Background paper for Mr. Whitley: Tobacco Product Placement. Tobacco Institute; 19890720, 1989. Access date: March 30, 2001.
Bates No. TIMN0203517-3518. URL: http://www.tobaccoinstitute.com/ getallimg.asp?DOCID=TIMN0203517/3518\&if=avtidx.

59 None. Philip Morris product placement guidelines and procedures. Philip Morris; No date, 1989. Access date: March 27, 2001. Bates No. 2023271431-1433. URL: http://www.pmdocs.com/ getallimg.asp? DOCID=2023271431/1433.

60 Freedman B. [Letter from Barton Freedman of BW to Thomas Luken]. Brown \& Williamson; February 23, 1989 Lorillard. Access date: March 30, 2001. Bates No. 91753651-3652. URL: http:// www.lorillarddocs.com/getallimg.asp? $i f=a v l i d x \& D O C I D=91753651 /$ 3652.

61 Pollay R. Promises, promises: self-regulation of US cigarette broadcast advertising in the 1960s. Tobacco Control 1994;3:134-44

62 None. Cigarette marketing code. Philip Morris; March 1993. Access date: March 27, 2001. Bates No. 2026121018-1021. URL: http://www.pmdocs.com/getallimg.asp?DOCID=2026121018/1021.

63 Devaney F. Product placement history. Rogers \& Cowan. April 12, 1990. Access date: March 30, 2001. Bates No. 507341906-1906. URL: http://www.rirtdocs.com/.

64 Degenhardt W. Product placement opportunity - Lucky Strike. American Tobacco; October 8, 1990. Access date: March 30, 2001. Bates No. 963040160. URL: http://www.bwdocs.aalatg.com/public.asp.

65 McMullen C. Competition and FTC. American Tobacco; September 5 , 1991. Access date: March 30, 2001. Bates No. 970029856. URL: http://www.bwdocs.aalatg.com/public.asp.

66 McMullen C. UPP entertainment marketing. American Tobacco; December 19, 1991. Access date: March 30, 2001. Bates No. 970196104-6105. URL: http://www.bwdocs.aalatg.com/public.asp.

67 Mullen C. Contract/agreement with C McMullen, Unique Product Placement, Inc. American Tobacco Co.; May 8, 1992. Access date: July 30, 2001. Bates No. $970110875-77$. URL: www.bw.aalatg.com/ public.asp.

68 RJR INTL RJR I JD. Authorization for change. HQ marketing: public relations agreement. R. J. Reynolds; November 3, 1990. Access date: April 2, 2001. Bates No. 515997144 . URL: http://www.rirtdocs.com/ rirtdocs/frames.html.

69 Federal Trade Commission. Cigar sales and advertising promotional expenditures for calendar years 1996 and 1997. Washington DC: FTC 1999.

70 Benes A. Pants on fire: Cigar Afficianado website/People, p. 4-5.

71 Klein A. The truth about cigars (reprinted from Baltimore Sun). Readers' Digest 1999; January: 137-44

72 Hazan A, Glantz S. Current trends in tobacco use on prime-time fictional television [letter] Am J Public Health 1995;85:116-17.

73 Hazan A, Lipton H, Glantz S. Popular films do not reflect current tobacco use. Am J Public Health 1994;84:998-1000.

74 Stockwell T, Glantz S. Tobacco use in increasing popular films. Tobacco Control 1997;6:282-4.

75 Teti T, Glantz S. Smoking in movies remained high is 1997. Tobacco Control 1998:7:441-2.

76 Everett S, Schnuth R, Tribble J. Tobacco and alcohol use in top-grossing American films. J Community Health 1998;23:317-24.

77 Escamilla G, Cradock A, Kawachi I. Women and smoking in Hollywood movies: a content analysis. Am J Public Health 2000;90:412-14.

78 Kacirk K, Glantz S. Smoking in movies in 2001 exceeded rates in the 1960s. Tobacco Control 2001;10:398-8.

79 Thumbs Up Thumbs Down. TUTD 2001 Report. American lung Association of Sacramento-Emegrant Trails; 2001.www.saclung.org

80 Shields DL, Carol J, Balbach ED, et al. Hollywood on tobacco: how the entertainment industry understands tobacco portrayal. Tobacco Control 1999;8:378-86.

81 National Association of Attorneys General. Master Settlement Agreement. 1998

82 Barbeau EM, DeJong W, Brugge DM, et al. Does cigarette print advertising adhere to the Tobacco Institute's voluntary advertising and promotion code? An assessment. Journal of Public Health Policy 1998; 19:473-88. 